\title{
Euphemisms in Article Online on Konsultasi Syariah
}

\author{
Rindi Puspita \\ English Applied Linguistics Study \\ Program, Postgraduate School \\ State University of Medan, \\ Indonesia \\ rindipuspita54@yahoo.com
}

\author{
Sri Minda Murni \\ English Applied Linguistics Study \\ Program, Postgraduate School \\ State University of Medan, \\ Indonesia \\ srimindamurni@gmail.com
}

\author{
Sumarsih \\ English Applied Linguistics Study \\ Program, Postgraduate School \\ State University of Medan, \\ Indonesia \\ prof.sumarsih@gmail.com
}

\begin{abstract}
Euphemism is a word or an expression which is delicate and inoffensive and is used to replace or cover a term that seems to be either taboo, too harsh or simply inappropriate for a given conversational exchange and is the substitution of a more pleasant or less direct word for an unpleasant or distasteful one. Euphemism is common in society, we can found euphemisms in mass media, internet, etc. Some euphemism use in religious language. Ovidu (2008) stated that in the religious language, the use of the euphemism is not necessarily due to modesty, but to fear. So based on Ovidu's statement the researchers will make a research about euphemism in religious language that used in article on Konsultasi Syariah. The data will be gathered by using documentary technique, the data will be limited on article that publish in 2018.
\end{abstract}

Keywords: euphemism, religious language, article

\section{INTRODUCTION}

Euphemism is a word or an expression which is delicate and inoffensive and is used to replace or cover a term that seems to be either taboo, too harsh or simply inappropriate for a given conversational exchange and is the substitution of a more pleasant or less direct word for an unpleasant or distasteful one. By using euphemism, we can make more polite statement, so, it will not make others fell unpleasant because the language conveyed has been smoothen. For example; we often choose the word 'restroom' for saying 'bathroom' or 'pass away' for saying 'dead'. In Indonesia euphemism, the word buta is euphemized as tunanetra.

According to Allan and Burridge (1991) is a euphemism is an expression intended by the speaker to be less offensive, disturbing, or troubling to the listener than the word or phrase it replaces [1].

Ovidu (2008) stated that in the religious language, the use of the euphemism is not necessarily due to modesty, but to fear [2]. Since the bans have a social character, the use and impact of euphemisms is linked to the social level, the domination relationship with other social circles of the individual and the social group. Thus, typically, a euphemistic term at a certain social level can be vulgar in another register or social level. Also, as the language evolves alongside the society, one of the effects of using this route is the mitigation (to extinction sometimes) of the consciousness that, indirectly, a ban is violated.
Konsultasi Syariah is a form for moeslim people to ask something that they do not know, the question is answered by Ulamas based on Holy Qur'an and hadists. In Konsultasi Syariah presents many chategories, Example about: marriage life, Aqidah, Halal and Haram, Adzan, Firqoh and many more.

Based on theory Allan and Burridge (1991) expectation, reality and gap can be taken as a discussion. The expectation from the theory euphemism is an expression intended by the speaker to be less offensive, disturbing, or troubling to the listener than the word or phrase it replaces. The expectation is euphemism that used in religion language is a word or an expression which is delicate and inoffensive and is used to replace or cover a term that seems to be either taboo, too harsh or simply inappropriate for a given conversational exchange and is the substitution of a more pleasant or less direct word for an unpleasant or distasteful one but according to Ovidu (2008) in the religious language, the use of the euphemism is not necessarily due to modesty, but to fear. So to realize that Ovidu's statement, the researcher add the preliminary data.

The following preliminary data found by the researcher on the website Konsultasi Syariah:

Data 1 :

The Article title: Hukum Laki-laki Memakai Pakaian Wanita untuk Pentas Seni Drama dan Karnaval (The Law of men wearing women's clothing to art performances of Drama and Carnival)

Published on: Aug 30, 2018 By Ustadz Ammi Nur Baits

Dalam hadis dari Ibnu Abbas Radhiyallahu 'anhuma, beliau mengatakan, (In the Hadith of Ibn Abbas Radhiyallahu 'anhuma' he said)

"Allah melaknat laki-laki yang menyerupai wanita, begitu pula wanita yang menyerupai laki-laki" (HR. Ahmad 3151 dan dishahihkan Syuaib al-Arnauth) ("Allah cursed men who imitate women, as did the women who resemble men" (HR. Ahmad and Saheeh 3151 Shu'ayb al-Arnauth) 
From the bold clause in Data one is a kind of euphemism because the sentence of laki-laki yang menyerupai wanita, begitu pula wanita yang menyerupai laki-laki (men who imitate women, as did the women who resemble men) is less offensive than word banci (transsexual). The sentence above is explain the question of "can men wear a women's clothes?", but that clause did not make fear the readers. Therefore Ovidu (2008) stated in the religious language, the use of the euphemism is not necessarily due to modesty, but to fear is not true.

Based on that researcher added more data to conclude euphemism words in Konsultasi Syariah make the readers fear or just to make taboo word less offensive and divided into some types of euphemisms. Therefore the researcher conducted the study about euphemism in article from Konsultasi Syariah.

\section{REVIEW OF LITERATURE}

According to Allan and Burridge (1991) is a euphemism is an expression intended by the speaker to be less offensive, disturbing, or troubling to the listener than the word or phrase it replaces. In real life, when people meet with some unpleasant things or behaviours, they usually choose some vague expressions to avoid making bold or hurting other's feeling, thus they choose to use euphemism. It softens the effect of what they really wish to communicate, avoiding, as much as possible, offence and conflict.

Euphemism is classified into five types (Williams 1975; Shipley 1977; Rawson 1983; Neaman \& Silver 1983; Allan \& Burridge 1991) as follows: Shortening. This types are divided into five, namely: abbreviation, apocopation, shorten or omit, backformation, diminutive, omission, and clipping. b. Circumlocution. c. Remodeling. This types are divided into three, namely: phonological distortion, blending, reduplication. d. Semantic Change. This types are divide into seven, namely: semantic shift, metaphorical transfer, widening, litotes, understatement, indirection and abstraction. e. Borrowing. This types are divided into two namely: external and internal borrowing [3].

\section{RESEARCH METHOD}

This study is conducted by using descriptive qualitative research design. This research is intended to describe euphemisms that used in article online on Konsultasi Syariah. The data of this research is the words that contain of euphemism that used in article online on Konsultasi Syariah website.

\section{DATA ANALYSIS}

The data taken from article or answer and question in Konsultasi Syariah website.
Data 1:

Apa hukum penjarahan mini market ketika suasana bencana, seperti gempa dan tsunami baru-baru ini? Apakah alasan bencana membolehkan hal itu? (What is the law of pillage mini markets when disasters, such as the recent earthquake and tsunami? Does the reason for disasters allow that?)

The bold word from the data above is kind of euphemism because penjarahan (pillage) is less offensive than mencuri (thieve). Penjarahan (pillage) is euphemism that include in widening types in semantic change because the word mencuri (thieve) is vivid than the word penjarahan (pillage). The word penjarahan (pillage) is a euphemism but did not make fear the reader because if someone says penjarahan (pillage) the listener do not fear. Therefore Ovidu (2008) stated in the religious language, the use of the euphemism is not necessarily due to modesty, but to fear is not true.

Data 2:

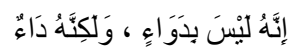

"Khamr itu bukan obat, namun itu penyakit." (HR. Muslim 1948) ("Khamr is not a medicine, but it is a disease." (Narrated by Muslim 1948))

In Data 2: the bold word Khamr is a euphemism because in Indonesia the word Alcohol is a taboo word because the majority religion in Indonesia is Moeslim, for Moeslim Alcohol is Haram, thus when we said Khamr is less offensive than Alcohol. Because of Khamr is Haram therefore when we said Khamar it can makes the hearer fear, because Khamr is Haram. Therefore Ovidu (2008) stated in the religious language, the use of the euphemism is not necessarily due to modesty, but to fear is true. Khamr is taken from Arabic language so Khamr is euphemism that include in external borrowing types.

Data 3

\section{Bahaya Ikhtilath}

\section{The Hazard of Ikhtilath}

In data 3: the bold word is euphemism because is more polite than mingled between man and woman. In Moeslim Ikhtilath is haram has a sin so if there are some Moeslim say Ikhtilath, it can make fear the reader. Therefore Ovidu (2008) stated in the religious language, the use of the euphemism is not necessarily due to modesty, but to fear is true. Ikhtilath is taken from Arabic language so Ikhtilath is euphemism that include in external borrowing types.

\section{Data 4}

Dalam hadis dari Ibnu Abbas Radhiyallahu 'anhuma, beliau mengatakan, (In the Hadith of Ibn Abbas Radhiyallahu 'anhuma' he said) 
"Allah melaknat laki-laki yang menyerupai wanita, begitu pula wanita yang menyerupai laki-laki” (HR. Ahmad 3151 dan dishahihkan Syuaib al-Arnauth) ("Allah cursed men who imitate women, as did the women who resemble men" (HR. Ahmad and Saheeh 3151 Shu'ayb al-Arnauth)

From the bold in data 4 is a kind of euphemism because the sentence of laki-laki yang menyerupai wanita, begitu pula wanita yang menyerupai laki-laki (men who imitate women, as did the women who resemble men) is less offensive than word banci (transsexual). The sentence above is explain the question of "can men wear a women's clothes?", but that clause did not make fear the readers. Therefore Ovidu (2008) stated in the religious language, the use of the euphemism is not necessarily due to modesty, but to fear is not true. The types of euphemism is circumlocution, because the words lakilaki yang menyerupai wanita, begitu pula wanita yang menyerupai laki-laki have more letters and syllables than the offensive word banci.

\section{FINDINGS}

Having analyzed the data of the research, the findings are described the types that make fear the reader based on Ovidu (2008) that stated in the religious language, the use of the euphemism is not necessarily due to modesty, but to fear. The types of euphemism that make fear is external borrowing. So not all euphemism in religious language use for fear, only some euphemism in certain types use to fear.

\section{REFERENCES}

[1] Allan, K, and Burridge, K. 1991. Euphemism University Press.

[2] Ovidiu, D., Parofonic (2008) Euphemism, in: Studies of Romanian Language in the Memory of Professor Radu Sp. Popescu, Universitaria Publishing House, Craiova,

[3] Kaosa-Ad, R. (2009). 'English Euphemism as Used by Native Speakers of English and of Thai'. Retrieved from http://thesis.swu.ac.th/swuthesis/Eng(M.A.)/Rommayasin_K.pdf,

[4] Yayasan Yufid Network. (2018-2019). Konsultasi syariah. Access on https://konsultasisyariah.com 